\title{
Root Length and $P$ Uptake Analysis in Five Elite Lentil (Lens culinaris Medikus) Lines Suitable for Northeast India Condition
}

\author{
Sapam Rajeshkumar ${ }^{\text {* }}$ and V. K. Khanna ${ }^{2}$ \\ ${ }^{1}$ Genetics and Plant Breeding, CPGS, CAU (I), Umiam, Meghalaya, India \\ ${ }^{2}$ School of Crop Improvement, CPGS, CAU (I), Umiam, Meghalaya, India \\ *Corresponding author
}

\section{A B S T R A C T}

\section{Keywords}

Root Length, P Uptake,

Elite Lentil, (Lens

culinaris Medikus)

Article Info

Accepted:

28 May 2018

Available Online:

10 July 2018
In spite of being the most consumed pulse of the NER, lentil is cultivated sporadically on relatively poor soils and in harsh environments with a little or no fertilizer after rice crop. Therefore, there is a need of identifying lentil germplasms that is adapted to low input acidic soils to achieve remunerative productivity. The present study was conducted to evaluate root length and P- uptake of five lentil genotypes under acidic and water acarcity conditions. From the studies of root traits and P-uptake we identified three lines viz., DPL62, IPL-220 and PL-04 which perform better in the stress conditions. The results of this study suggest that the variation in root morphology of the five varieties is pronounced, without the variation in the ability to induce chemical (rhizosphere $\mathrm{pH}$ ) and biochemical (Aptase) change in the rhizosphere environment through root exudation.

\section{Introduction}

Lentil (Lens culinaris Medikus) is a diploid $(2 n=2 x=14) \quad$ self-pollinating annual cool season grain legume, with a relatively large genome of 4,063 Mbp (Arumuganathan and Earle, 1991). It has great significance in cereal-based cropping systems because it fixes nitrogen. The protein content in the seed is 22 to $35 \%$ and it is also rich in $\mathrm{Fe}, \mathrm{Zn}$ and Vitamins. Lentil is used as food, feed and in sustainable farming systems. Lentils have been grown extensively in the semi-arid parts of the world, where they have slightly lower yields, but good seed quality. High humidity and excessive rainfall during the season encourages vegetative growth, which prevents good yield and can reduce seed quality. Ten to twelve inches of annual rainfall will produce high yields of good quality seed. Excessive drought and/or high temperatures during the flowering and pod-fill period also reduce yields. Almost all soils are phosphorus deficient and large quantities of phosphorus have been added to our agricultural soils since we began farming. Plants absorb phosphorus from the soil solution, but many soils rapidly immobilize phosphorus into insoluble forms.

This happens in both acid and alkaline soils, although different chemical reactions are responsible in each case.

Lentil are typically grown and adapted to neutral to alkaline soils but yields are compromised where soils are acidic, sodic and 
saline or have high levels of boron. Alleviating such toxicity problems through soil modification is not an economic or practical solution and therefore growing more tolerant cultivars is considered the best approach to overcoming these constraints (Materne and Siddique, 2009). Rice is one of the major crops of northeast region of India and after harvest most of the land remains fallow during rabi season in hilly areas. Rice fallow areas offer a huge potential niche for short season pulses and oilseed crops. There is erratic rainfall during rabi and unavailability of irrigation water in hilly regions. In spite of being the most consumed pulse of the NER, lentil is cultivated sporadically on relatively poor soils and in harsh environments with a little or no fertilizer after rice crop. Therefore, there is a need of identifying lentil germplasm that is adapted to low input acidic soils to achieve remunerative productivity. The present study was undertaken analyze the root lengths and phosphorus uptake in elite genotypes and identify better performer under acidic and water scarcity condition.

\section{Materials and Methods}

The root growth and length of the five varieties was studied in a pot experiment (Fig. 1) in CPGS, CAU (I), Umiam, Meghalaya. Five elite lentil lines performing well in this region were evaluated for various, Morphological - Root lengths al 40, 65 and 90 DAS; Physiological: Rhizosphere $\mathrm{pH}$, and Exo-cellular phosphatase enzymes

\section{Determination of root growth and length in pot culture}

Pots were made by cutting two litre transparent plastic bottles. They were filled with $2.5 \mathrm{kgs}$ of soil ( $\mathrm{pH} \mathrm{4.5)}$ by shaking to achieve soil bulk density of $1.4 \mathrm{~g} \mathrm{~cm}^{-3}$. The soil columns of all the pots have to be $25 \mathrm{~cm}$ high. The pots were placed in the open, sides of pots were wrapped in black polythene to prevent exposure of roots to light and maintained at $20 \%$ soil moisture by weighing and adding water. At 40, 65 and 90 DAS, shoots were cut and stored in paper bags for drying. The total lengths of the root system were measured using Dt-Scan software.

\section{Nutrient uptake analysis for Phosphorus}

Shoots of the pot experiment at flowering stage (60 DAS) were dried at $60^{\circ} \mathrm{C}$ until it attains constant weight. Nutrient analysis for phosphorus were done. Nitrogen $(\mathrm{N})$ was not analyzed, because lentil, a legume, can fix Atmosperic $\mathrm{N}_{2}$.

\section{Digestion of plant material}

Shoots of the pot experiment at flowering stage (60 DAS) was dried at $60^{\circ} \mathrm{C}$ until constant weight was recorded. The plant material $(0.5 \mathrm{~g})$ was digested using $70 \mathrm{~mL}$ test tubes with di-acid mixtures. The dry weight was taken for the leaf and was digested in diacid $\left(\mathrm{HNO}_{3}: \mathrm{HCLO}_{4}\right)$ at 3:1 ratio and incubated for one month for complete digestion of leaves of each samples. $1 \mathrm{ml}$ of digested sample was diluted to $50 \mathrm{ml}$ and filtered through watman paper. Again now 10 $\mathrm{ml}$ reaction mixture was prepared by adding 2 $\mathrm{ml}$ Ammonium vanadate, $1 \mathrm{ml}$ sample and 7 $\mathrm{ml}$ Millipore water. Blank was prepared by adding $2 \mathrm{ml}$ Ammonium Vanadate and $8 \mathrm{ml}$ $\mathrm{H}_{2} \mathrm{O}$. The standard curve for $\mathrm{P}$ was prepared in a concentration range of $0,0.1,0.2,0.3 ., 0.4$, $0.5,0.6,0.7,0.8,09$ and 1 ppm. $\mathrm{P} \%=$ \{Concentration / wt. of sample (g) $\}$ x $\{100 /$ Aliquote $(\mathrm{ml})$ taken $\mathrm{x}$ \{Volume of digest $(\mathrm{ml}) / 10,000\} . \mathrm{P}$ Uptake $=$ Plant dry weight $(\mathrm{g})$ $\mathrm{x} \mathrm{P}$ content (mg).

\section{Determination of rhizosphere $\mathrm{pH}$}

Root induced rhizosphere $\mathrm{pH}$ is known to influence availability of soil inorganic 
phosphorus and micro-nutrients to plants. The roots of 10-days-old seedlings of the five lentil varieties were embedded in agar containing $\mathrm{pH}$ indicator dye Bromocresol purple and adjust to $\mathrm{pH} 6$ (Marschner and Romheld, 1983). The root-induced $\mathrm{pH}$ changes, revealed by colour change were recorded after one hour following the agar embedding (Fig. 3.6)

\section{Rhizosphere acid phosphatase (Aptase) activity}

Aptase catalyzes the conversion of soil organic phosphorus into plant available inorganic phosphorus. Intact roots of 10-daysold seedlings were sandwiched between two layers of filter papers, soaked in a mixture of Fast Red TR (dye) and 1-naphtylphosphate (substrate). If the roots release phosphatase enzymes then it will give a range of brownish red colour (Dinkelaker and Marschner, 1992).

\section{Results and Discussion}

The root length recorded a continuous increase throughout the period of observation. Among the genotypes highest root length at 40 DAS was recorded by G1 (DPL-62) and it was at par with G3 (PL-8) showing that these genotypes have early root growing habit and has potential of high root length. At 65 DAS and 90 DAS genotypes G1 (DPL-62) and G3 (PL-8) had higher root length than others indicating that these genotypes have high root lengths irrespective of acidic levels and water deficit levels (Table 1). Ahmed et al., (2014) and Gahoonia et al., (2005) also reported similar findings with the present study.

For the five genotypes under study, root growth rate from 40 DAS to 65 DAS is higher than from 65 DAS to 90 DAS, while for the genotype LRIC-560335, and L-4581 the change in root length from 65 DAS to 90 DAS is almost the same indicating that there is not much growth in root length after rapid growth till 65 DAS. Alami-Milani et al., (2013) also reported similar results with the current findings about yield related traits.

Root length recorded throughout the crop growing period under irrigated condition (B2) is higher than water deficit condition (B1) whereas root length recorded in normal soil $\mathrm{pH}$ is higher than in acidic $\mathrm{pH}$ soil.

Among the interactions, at 40 DAS, the highest root length was shown by the interaction PL-8 which had the highest root length under water deficit and normal soil $\mathrm{pH}$ conditions which are at par with the root length of genotypes LRIC-560335, DPL- 62 and L-4581 under water deficit and acidic conditions.

These results corroborate with the results of study conducted by Gahoonia et al., (2005) in lentil and Kumar et al., (2013) in paddy.

At 65 DAS, LRIC-560335, DPL-62 and PL-8 had higher root length under water deficit and acidic soil conditions. Also these genotypes had nearly same root lengths under acidic conditions showing that they are less affected by soil acidic conditions.

Interaction studies of genotypes $\mathrm{x}$ water deficit levels x soil acidity levels for root length after 90 DAS showed that IPL-220, DPL-62 and PL-8 had higher root length under water deficit and normal $\mathrm{pH}$ soil conditions (Table 2). Genotypes DPL-62, PL-8 and IPL-220 had higher root length under water deficit and acidic conditions suggesting that these genotypes are well adapted to drought and acidic soils. DPL-62 and LRIC-560335 had higher root length under irrigated and normal $\mathrm{pH}$ soil conditions and PL-8, IPL-220 and DPL-62 showed higher root length under irrigated and acidic soil $\mathrm{pH}$ conditions. These results are in conformity with the findings of Roy et al., (2009). 
Table.1 Root length, P-content and P-uptake parameters of lentil genotypes as influenced by soil acidity levels and water deficit levels

\begin{tabular}{|c|c|c|c|c|c|c|}
\hline \multirow{2}{*}{$\begin{array}{l}\text { Sl. } \\
\text { No. }\end{array}$} & \multirow[t]{2}{*}{ Treatments } & \multicolumn{3}{|c|}{ Root length after } & \multirow{2}{*}{$\begin{array}{l}\text { P- Content } \\
\text { ( } \% \text { of dry } \\
\text { matter })\end{array}$} & \multirow[t]{2}{*}{ P- Uptake } \\
\hline & & 40 DAS & 70 DAS & 90 DAS & & \\
\hline \multicolumn{7}{|c|}{ Genotypes } \\
\hline 1 & G1 & 10.399 & 18.566 & 26.655 & 0.138 & 0.734 \\
\hline 2 & G2 & 8.898 & 15.186 & 23.861 & 0.129 & 0.736 \\
\hline 3 & G3 & 10.190 & 18.513 & 25.674 & 0.142 & 0.729 \\
\hline 4 & G4 & 6.417 & 16.135 & 15.840 & 0.135 & 0.451 \\
\hline \multirow[t]{2}{*}{5} & G5 & 5.571 & 12.888 & 14.581 & 0.070 & 0.229 \\
\hline & CD 5\% & 2.046 & 3.449 & 2.804 & 0.290 & 0.170 \\
\hline \multicolumn{6}{|c|}{ Water deficit levels } & \\
\hline 1 & B1 & 9.581 & 14.018 & 17.988 & 0.122 & 0.494 \\
\hline \multirow[t]{3}{*}{2} & B2 & 7.009 & 18.498 & 24.657 & 0.127 & 0.658 \\
\hline & CD 5\% & 1.294 & 2.181 & 1.773 & 0.19 & 0.108 \\
\hline & & \multicolumn{3}{|c|}{ Soil acidity levels } & & \\
\hline 1 & $\mathrm{C} 1$ & 8.780 & 17.402 & 22.555 & 0.150 & 0.696 \\
\hline \multirow[t]{2}{*}{2} & $\mathrm{C} 2$ & 7.810 & 15.113 & 20.090 & 0.095 & 0.456 \\
\hline & CD 5\% & 1.294 & 2.181 & 1.773 & 0.19 & 0.108 \\
\hline
\end{tabular}

Table.2 Interaction effect (Genotypes X Water deficit level X Soil acidity levels) on five parameters of lentil

\begin{tabular}{|c|c|c|c|c|c|c|}
\hline \multirow{2}{*}{$\begin{array}{l}\text { Sl. } \\
\text { No. }\end{array}$} & \multirow[t]{2}{*}{ A X B X C } & \multicolumn{3}{|c|}{ Root length after } & \multirow{2}{*}{$\begin{array}{l}\text { P- content } \\
\text { (\% of dry } \\
\text { matter) }\end{array}$} & \multirow[t]{2}{*}{ P- Uptake } \\
\hline & & 40 DAS & 65 DAS & 90 DAS & & \\
\hline 1 & G1B1C1 & 11.225 & 20.245 & 29.020 & 0.111 & 1.115 \\
\hline 2 & $\mathrm{G} 2 \mathrm{~B} 1 \mathrm{C} 1$ & 13.850 & 20.980 & 29.350 & 0.156 & 0.720 \\
\hline 3 & G3B1C1 & 7.814 & 15.630 & 30.000 & 0.102 & 1.215 \\
\hline 4 & G4B1C1 & 8.706 & 17.410 & 20.250 & 0.171 & 0.485 \\
\hline 5 & G5B1C1 & 10.330 & 14.570 & 18.350 & 0.102 & 0.495 \\
\hline 6 & G1B1C2 & 12.005 & 19.665 & 29.650 & 0.169 & 1.100 \\
\hline 7 & $\mathrm{G} 2 \mathrm{~B} 1 \mathrm{C} 2$ & 5.815 & 18.625 & 29.455 & 0.150 & 1.685 \\
\hline 8 & G3B1C2 & 7.443 & 14.885 & 28.540 & 0.166 & 1.065 \\
\hline 9 & G4B1C2 & 12.690 & 21.235 & 23.100 & 0.121 & 0.675 \\
\hline 10 & G5B1C2 & 11.475 & 19.625 & 24.100 & 0.110 & 0.730 \\
\hline 11 & G1B2C1 & 8.209 & 16.420 & 28.435 & 0.198 & 0.625 \\
\hline 12 & G2B2C1 & 8.385 & 16.770 & 23.510 & 0.181 & 1.985 \\
\hline 13 & G3B2C1 & 5.835 & 13.840 & 21.700 & 0.107 & 1.230 \\
\hline 14 & G4B2C1 & 4.800 & 20.640 & 26.900 & 0.173 & 0.630 \\
\hline 15 & G5B2C1 & 5.885 & 11.765 & 17.045 & 0.093 & 1.175 \\
\hline 16 & G1B2C2 & 9.149 & 18.295 & 25.715 & 0.179 & 1.170 \\
\hline 17 & $\mathrm{G} 2 \mathrm{~B} 2 \mathrm{C} 2$ & 6.485 & 18.170 & 28.350 & 0.169 & 1.210 \\
\hline 18 & G3B2C2 & 7.115 & 16.005 & 26.125 & 0.178 & 1.260 \\
\hline 19 & G4B2C2 & 3.814 & 7.630 & 13.210 & 0.051 & 0.160 \\
\hline 20 & G5B2C2 & 4.871 & 9.745 & 20.640 & 0.080 & 0.285 \\
\hline & CD 5\% & 4.091 & 6.898 & 5.607 & 0.590 & 0.340 \\
\hline
\end{tabular}

Where, G1: DPL-62, G2: IPL-220, G3: PL-8, G4: LRIC 560335, and G5: L-4581, B1: water deficit, B2: Irrigated, $\mathrm{C} 1$ : Normal Soil $\mathrm{pH}$ and $\mathrm{C} 2$ : Acidic soil $\mathrm{pH}$. 
Fig.1 A) Transparent plastic bottle experiment B) Five genotypes of lentil grown under acidic soil conditions
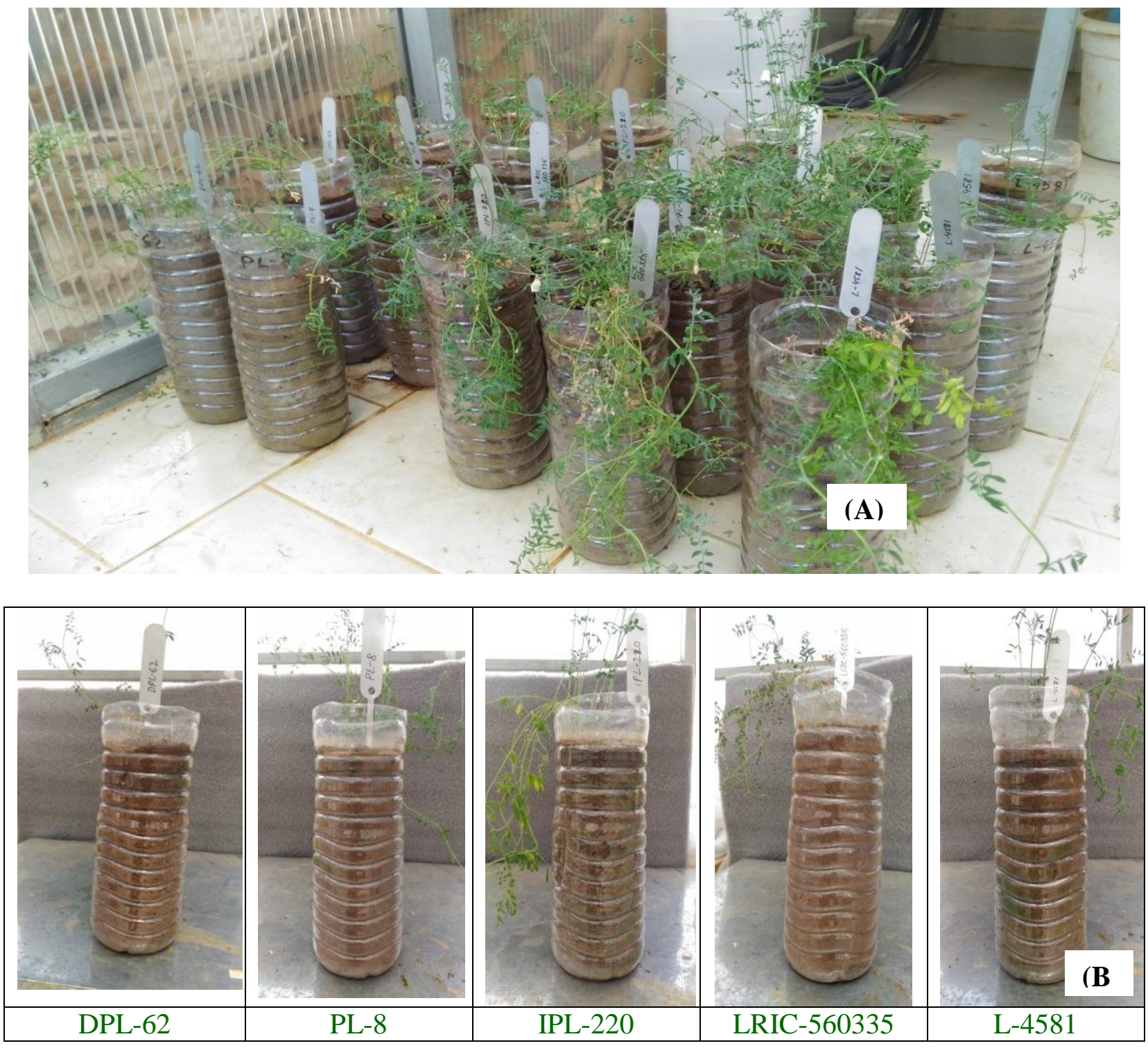

Significant higher P-content was recorded with lentil genotype PL-220 and it is at par with lentil genotypes DPL-62 and LRIC560335. Lentil genotype PL-8 scored highest in P-uptake and is at par with genotypes DPL62 and PL-220 Indicating that these genotypes can give high yield even in lesser input (Phosphorus) soil conditions. Reports from the experiment conducted by Gahoonia et al., (2001) also corroborate with the results of the present study.

From the interaction studies of genotypes $\mathrm{x}$ water deficit levels $\mathrm{x}$ soil acidity levels for $\mathrm{P}$ content and P- uptake Interactions, genotypes IPL-220 and DPL-62 had higher P- content under water deficit and normal soil $\mathrm{pH}$ conditions. Genotypes IPL-220 and DPL-62 showed higher P-uptake under water deficit and normal soil $\mathrm{pH}$ conditions suggesting that these genotypes can perform well under such 
stress conditions. Krasiliniko et al., (2003) also reported similar results in Cowpea.

Among water deficit and acidic soil conditions DPL-62, IPL-220 and PL-8 had higher P-content, while lentil genotypes DPL62, PL-8 and IPL-220 had higher P-uptake. Genotypes DPL-62, IPL-22 and LRIC560335 recorded high P-content under irrigated and normal soil $\mathrm{pH}$ conditions indicating that these genotypes perform better under well irrigated and normal soil $\mathrm{pH}$ conditions whereas PL-8, IPL-220 and LRIC560335 had higher P-uptake under similar conditions.

Among irrigated and acidic soil conditions IPL-220, PL-8 and DPL-62 scored higher in both $\mathrm{P}$ - content and P-uptake indicating that these genotypes can give high yield also under low P- input acidic soils. Alami-Milani et al., (2013) also reported similar results.

In pot experiment, DPL-62, PL-8 and IPL220 absorbed significantly higher amount of P-nutrients and such ability of these genotypes may have supported them to produce higher grain yields in field trials. Lentil is a rain-fed winter crop and winter is dry in Northeast India.

Therefore, in addition to higher absorption of soil P-nutrients, better capture of soil moisture might have played a role in better performance of these genotypes, which was not investigated in the present study.

The results of this study suggest that the variation in root morphology of the five varieties is pronounced, without the variation in the ability to induce chemical (rhizosphere $\mathrm{pH}$ ) and biochemical (Aptase) change in the rhizosphere environment through root exudation. Root induced rhizosphere $\mathrm{pH}$ is known to influence availability of soil inorganic phosphorus (Gahoonia and Nielsen, 1992) and micro-nutrients to plants
(Marschner and Romheld, 1996). The role of Aptase for catalyzing the conversion of soil organic phosphorus into plant available inorganic phosphorus is also reported (Asmar et al., 1995).

The lack of variation in the rhizosphere $\mathrm{pH}$ and Aptase among the five varieties and Pnutrient mobilizing processes, suggested that root morphology traits enhancing the exploration of soil for P-nutrients and water might be a criterion worth giving more attention for the selection of P-nutrient efficient and drought tolerant varieties for nutrient limiting and dry soils. This finding is supported by the results of other recent studies where genetic diversity was found in root size of lentil (Sarker et al., 2005) and soybean (Wang et al., 2004), common bean (Yan and Lynch, 1998) and cowpea (Krasilniko et al., 2003).

From the studies of root traits and P-uptake we identified three lines viz., DPL-62, IPL220 and PL-04 which perform better in the stress conditions.

The results of this study suggest that the variation in root morphology of the five varieties is pronounced, without the variation in the ability to induce chemical (rhizosphere $\mathrm{pH})$ and biochemical (Aptase) change in the rhizosphere environment through root exudation.

\section{References}

Ahmed, B., Pramanik, M.E.A., Sultana, D., Rahman, M.M. and Choudhury, R.U. (2014). Study of Selected Lentil Genotypes against Rainfed in Barind Drought. Int. J. Bus. Soc. Sci. Res., 2(2): 145-147.

Alami-Milani, M., Amini, R., Mohammadinasab, A.D., Shafagh-kalvanegh, J., Asgharzade, A. and Emaratpardaz, J. (2013). Yield and yield components of lentil (Lens culinaris 
Medick.) affected by drought stress and mulch.

Arumuganathan, K. and Earle, E.D. (1991). Nuclear DNA content of some important plant species. Plant molecular biology reporter, 9(3): 208-218.

Asmer F, Gahoonia T.S and Nielsen N.E. (1995). Barley genotypes differ in activity of extracellular phosphatase and depletion of organic phosphorus in the rhizosphere soil. Plant Soil 172, 117-122.

Dinkelaker, B. and Marschner, H. (1992). In vivo demonstration of acid phosphatase activity in the rhizosphere of soil-grown plants. Plant and Soil, 144(2): 199-205.

Gahoonia T S and Nielsen N E 1992. The eff ect of root induced $\mathrm{pH}$ changes on the depletion of inorganic and organic phosphorus in the rhizosphere. Plant Soil 143, 185-189.

Gahoonia, T.S., Ali, O., Sarker, A., Nielsen, N.E. and Rahman, M.M. (2005). Genetic variation in root traits and nutrient acquisition of lentil genotypes. Journal of Plant Nutrition, 29(4), 643-655.

Gahoonia, T.S., Nielsen, N.E., Joshi, P.A. and Jahoor, A. (2001). A root hairless barley mutant for elucidating genetics of root hairs and phosphorus uptake. Plant Soil, 235, 211-219

Krasiliniko, G., Gahoonia, T.S. and Nielsen, N.E. (2003). Variation in phosphorus uptake of cowpea genotypes (Vigna unguiculata) due to differences in root and root hair length and root-induced rhizosphere processes. Plant Soil, 251: 83-91.

Kumar, A., Pandey, A. and Pattanayak, A. (2013). Evaluation of rice germplasm under jhum cultivation in North East India and breeding for Aluminium tolerance. Indian Journal of Genetics and Plant Breeding, 73: 153-161.

Marschner, H and Ro“ mheld, V. (1983). In vivo measurements of root induced $\mathrm{pH}$ change at soil-root interface. Eff ect of plant species and nitrogen source. Z. Pflanzenphysiol. 111, 241-251

Marschner, H. and Romheld, V. (1996). Root included changes in the availability of micronutrients in the rhizosphere. In Plant Roots: The Hidden Half. Eds. Y. Waisel, A. Eshel and U. Kafkaki, pp. 557-580. Marcel Dekker, Inc. New York, basel, Hong Kong.

Materne, M. and Siddique, K.H.M. (2009). Agroecology and crop adaptation. The lentil: botany, production and uses. MPG Books Group, London, pp.47-63.

Roy, A., Aich, S.S., Bhowmick, M.K. and Biswas, P.K. (2009). Response of lentil varieties to sowing time in plains of West Bengal. Journal of crop and weed, 5 (2): 92-94.

Sarker, A., Erskine, W. and Singh, M. (2005). Variation in shoot and root characteristics and their association with drought tolerance in lentil landraces. Genetic Resources and Crop Evolution, 52(1): 89-97.

Wang, L., Liao, H., Yan, X., Zhuang, B. and Dong, Y. (2004) Genetic variability for root hair traits as related to phosphorus status in soybean. Plant Soil, 261: 77-84.

Yan, X. and Lynch, J.P. (1998) Genetic variation for root hair density and length in common bean in response to low phosphorus availability. In Phosphorus in Plant Biology: Regulatory Roles in Molecular, Cellular, Organisms and Ecosystem Processes. Eds. J P Lynch and J. Deikman. American Society of Plant Physiologist, Vol.19, Rockville, Maryland, USA.

\section{How to cite this article:}

Sapam Rajeshkumar and Khanna V. K. 2018. Root Length and P Uptake Analysis in Five Elite Lentil (Lens culinaris Medikus) Lines Suitable for Northeast India Condition. Int.J.Curr.Microbiol.App.Sci. 7(07): 4290-4296. doi: https://doi.org/10.20546/ijcmas.2018.707.500 